\title{
Biblioteki na Podgórzu koło Torunia w latach 1920-1939
}

\section{Wprowadzenie}

Niniejsze opracowanie jest próbą charakterystyki działalności bibliotek i środowiska czytelniczego, w którym działały placówki biblioteczne na Podgórzu k. Torunia w okresie 1920-1939. Materiał źródłowy, bardzo niejednorodny, oparty został na kwerendzie w archiwach państwowych w Bydgoszczy i Toruniu oraz na analizie artykułów zamieszczonych w toruńskiej prasie lokalnej. Cennym uzupełnieniem były rozmowy z Tadeuszem Zakrzewskim i Marią Teresą Cieślak, która udostępniła autorce materiały ze swego rodzinnego archiwum. Zgromadzone źródła wymusiły poświęcenie więcej uwagi jednej z bibliotek - bibliotece Bractwa Niepokalanie Poczętej NMP. Analizowane książnice podgórskie prowadziły swą działalność w międzywojniu mimo zmian administracyjnych Podgórza, dlatego cezura czasowa nie uwzględniła momentu oficjalnego włączenia miejscowości do Torunia w 1938 r. i wykład jest kontynuowany do roku 1939.

Nie powstała dotąd żadna monografia dotycząca bibliotek na Pomorzu w tym okresie ${ }^{1}$, nie ma również całościowego opracowania tego za-

${ }^{1}$ Do druku została przygotowana część V Historii Pomorza dotycząca okresu po 1918 r., a tamże rozdział autorstwa Przemysława Olstowskiego Szkolnictwo, oświata, ruch naukowy, biblioteki i muzea w województwie pomorskim w latach 1920-1939, gdzie zamieszczono syntetyczną charakterystykę dziejów bibliotek pomorskich, bez bibliotek Podgórza. 
gadnienia dla międzywojnia w Polsce². Dotychczas ukazały się jedynie prace Wandy Ciszewskiej o książnicach w Toruniu w latach 1945-1950 oraz trzy pierwsze części artykułu Katarzyny Tomkowiak charakteryzujące biblioteki w Toruniu w latach 1920-1939³. Poszczególnymi zagadnieniami Podgórza okresu międzywojennego zajmowali się: Irena Janosz-Biskupowa, Piotr Kurlenda, Andrzej Mietz, Marcjanna Połaszewska i Tadeusz Zakrzewski ${ }^{4}$. 0 samym Podgórzu traktuje monograficzne wydawnictwo jubileuszowe 450 lat toruńskiego Podgórza 1555-2005, w którym zaledwie wspomniano o okresie międzywojennym ${ }^{5}$. Działalność bibliotek podgórskich w tamtym czasie została zaprezentowana w 2005 r. przez K. Tomkowiak na jednym ze spotkań bibliofilskich w Toruniu ${ }^{6}$. W tym też roku ukazał się odrębny artykuł tejże o bibliotece Bractwa Niepokalanie Poczętej NMP ${ }^{7}$.

2 O polskich bibliotekach w okresie II Rzeczypospolitej zob. Biblioteki Oświatowe. Spis na dzień 1 I 1930 roku oraz Tablice statystyczne, Warszawa 1932; Biblioteki Wielkopolski i Pomorza, pod red. S. Wierczyńskiego, Poznań 1929; Biblioteki na wschodnich ziemiach II Rzeczypospolitej. Informator, pod red. B. Bieńkowskiej, Poznań 1998; Z. Gaca-Dąbrowska, Bibliotekarstwo II Rzeczypospolitej. Zarys problemów organizacyjnych i badawczych, Wrocław 1983; Straty bibliotek w czasie II wojny światowej w granicach Polski z 1945 r. Wstępny raport o stanie wiedzy, pod red. A. Mężyńskiego, cz. 1-3, Warszawa 1994.

3 W. Ciszewska, Biblioteki Torunia w latach 1945-1950, „Folia Toruniensia”, R. 5: 2005, s. 73-91; K. Tomkowiak, Biblioteki w Toruniu w latach 1920-1939 (część I), „Folia Toruniensia”, R. 4: 2004, s. 61-94; taż, Biblioteki w Toruniu w latach 1920-1939 (część II), „Folia Toruniensia”, R. 5: 2005, s. 51-72; taż, Biblioteki w Toruniu w latach 1920-1939 (część III), „Folia Toruniensia”, R. 6: 2006, s. 45-56.

4 I. Janosz-Biskupowa, Dzieje miasta Podgórza (1555-1938), „Zapiski Historyczne”, t. 27: 1962, z. 3, s. 376-386; P. Kurlenda, Działalność społeczno-polityczna Kościoła katolickiego w Toruniu i Podgórzu (1920-1939), Toruń 1997; A. Mietz, Rozwój przestrzenny i budownictwo na Podgórzu w latach 1920-1938, „Rocznik Toruński”, R. 11: 1976, s. 93-116; M. Połaszewska, Miasteczko w cieniu Torunia. Dzieje Podgórza w latach 1920-1938 ze szczególnym uwzględnieniem kwestii społeczno-kulturalnych, praca magisterska napisana pod kierunkiem prof. dra hab. Mieczysława Wojciechowskiego, Toruń 2006, Książnica Kopernikańska, Dział Zbiorów Specjalnych, sygn. KM rps 660; taż, Włączenie Podgórza do Torunia w latach Drugiej Rzeczypospolitej, „Rocznik Toruński”, R. 34: 2007, s. 95-120; T. Zakrzewski, Dzieje chórów kościelnych miasta Podgórza przed jego włączeniem do Torunia (1918-1938), „Rocznik Toruński”, R. 28: 2001, s. 123-139.

${ }^{5}$ K. Ciesielska, T. Zakrzewski, 450 lat toruńskiego Podgórza, Toruń 2005.

69 lutego 2005 r. na spotkaniu Towarzystwa Bibliofilów im. J. Lelewela w Toruniu Katarzyna Tomkowiak wystąpiła z referatem „Biblioteki miasta Podgórza w okresie międzywojennym".

7 K. Tomkowiak, Biblioteka Bractwa Niepokalanie Poczętej Najświętszej Marii Panny Królowej Korony Polskiej w Podgórzu k. Torunia w latach 1929-1939, [w:] Nad Bałtykiem, pod red. Z. Karpusa, J. Kłaczkowa, M. Wołosa, Toruń 2005, s. 425-437. 
Podgórz od czasu dziewiętnastowiecznego referendum (26 marca 1833 r.) funkcjonował jako gmina wiejska ${ }^{8}$, próby uzyskania praw miejskich powiodły się dopiero po odzyskaniu niepodległości przez państwo polskie. Na mocy uchwały Rady Ministrów z 29 grudnia 1924 r. Podgórz otrzymał status miasta, co definitywnie potwierdził wojewoda pomorski reskryptem z 15 lutego $1926 \mathrm{r}^{9}{ }^{9} \mathrm{~W}$ okresie dwudziestolecia międzywojennego Podgórz powiększył dynamicznie liczbę mieszkańców, wśród których przeważali Polacy, pod względem wyznania głównie katolicy, dobrze rozwijał się gospodarczo, chociaż z problemem bezrobocia przyszło się zmierzyć również władzom tego miasta. Podgórz utracił odrębność miejską na mocy uchwały Rady Ministrów z 17 grudnia 1936 r., jednak faktycznie przyłączenie do Torunia nastąpiło dopiero 1 kwietnia 1938 r.; używano wówczas nazwy Toruń-Podgórz ${ }^{10}$. W okresie II RP parafia podgórska należąca do archidiecezji gnieźnieńsko-poznańskiej ${ }^{11}$ wykazywała stały dynamiczny przyrost, w okresie 1920-1937 nastąpiło podwojenie liczby parafian ${ }^{12}$, a w 1939 r. notowano już 8500 osób ${ }^{13}$. Proboszczem parafii św. św. Piotra i Pawła był ks. Józef Domachowski ${ }^{14}$. Podgórz w okresie

${ }^{8}$ Cz. Frankiewicz, Dzieje miast Rzeczypospolitej Polskiej. Polska w słowie i obrazach. Miasta Polski nadmorskiej, t. IV: Dzieje Torunia, Bydgoszczy i miast okolicznych, Poznań 1930, s. 68-70; H. Maercker, Geschichte der ländlichen Ortschaften und der drei kleineren Städte des Kreises Thorn, Danzig 1899-1900, s. 120 n.; Słownik geograficzny Królestwa Polskiego i innych krajów słowiańskich, t. VIII, Warszawa 1887, s. 381; O. L. E. Steinmann, Der Kreis Thorn. Statistische Beschreibung, Thorn 1866, s. 261; S. Cackowski, Miasta dobrzyńskie i kujawskie w końcu XVIII wieku (1793-1807), Włocławek 1995; por. przyp. 4, 5.

9 Dziennik Urzędowy [dalej cyt. DzUrz] RP 1924 nr 107, poz. 1060.

10 DzUrz RP 1937 nr 29, poz. 217; 1938 nr 19, poz. 150; „Słowo Pomorskie” 1938, nr 77 (3 IV), s. 5; M. Połaszewska, Włączenie Podgórza..., s. 95-96; R. Sudziński, Przekształcenia strukturalne miasta Torunia w latach 1920-1975, Toruń 1993, s. 53-54.

${ }_{11}$ Kiedy powstała parafia podgórska?, „Wiadomości Kościelne Parafii Podgórz” 1934, nr 10 (4 II), s. 4; O. L. E. Steinmann, dz. cyt., s. 335; P. Kurlenda, dz. cyt., s. 19, 25.

12 Statystyka parafialna za rok 1932, „Wiadomości Kościelne Parafii Podgórz” 1933, nr 12 (12 II), s. 4; Statystyka parafialna, „Wiadomości Kościelne Parafii Podgórz” 1933, nr 13 (19 II), s. 4; P. Kurlenda, dz. cyt., s. 25.

13 S. Grochowina, Związki wyznaniowe w Toruniu 1939-1945, „Rocznik Toruński”, R. 30: 2003, s. 118.

${ }_{14}$ Księga Pamiqtkowa Pomorskiej Ligi Obrony Powietrznej Państwa, Torun 1925, s. 56, 133; Sprawozdanie Zarzq̨du Komitetu Wojewódzkiego LOPP w Toruniu za rok 1930, Toruń 1931, s. 26; P. Kurlenda, dz. cyt., s. 37, 118-119; T. Zakrzewski, Józef Domachowski (1876-1940), [w:] Toruński słownik biograficzny [dalej cyt. TSB], pod red. K. Mikulskiego, t. 3, Toruń 2002, s. 52-53; tenże, Józef Domachowski (1876-1940) ks. proboszcz parafii św. św. Piotra i Pawła na toruńskim Podgórzu, [w:] Słownik biograficzny Pomorza Nadwiślańskiego [dalej cyt. SBPG], suplement I, Gdańsk 1998, s. 69-70; „Zapiski Historyczne”, t. 11: 1939-1945, nr 5, s. 106. 
lat międzywojennych był siedzibą wielu stowarzyszeń i związków ${ }^{15}$, działały tam także bractwa i stowarzyszenia pobożne, spełniające ważną rolę nie tylko religijną, ale i społeczną. Swą aktywnością obejmowały zarówno członków, jak i całą społeczność lokalną. W okresie dwudziestolecia pośród nich znalazło się także Bractwo Niepokalanie Poczętej NMP, które działało wyłącznie na Podgórzu ${ }^{16}$.

\section{Biblioteka Bractwa Niepokalanego Poczęcia NMP Królowej Korony Polskiej}

$\mathrm{N}^{2}$ ajwiększym księgozbiorem Podgórza była założona w 1929 r. biblioteka Bractwa Niepokalanego Poczęcia NMP Królowej Korony Polskiej na Podgórzu k. Torunia (biblioteka rzeczywistą działalność rozpoczęła w styczniu 1930 r. $)^{17}$. Artykuł 2 Statutu Bractwa NPNMP określał jego cel jako: „Milicja Niepokalanie Poczętej Najświętszej Marji Panny Królowej Polski, w ścisłej łączności z Akcją Katolicką". Na mocy art. 3 p. 5 Statutu, Bractwo utrzymywało stałą bibliotekę katolicką i abonowało „ważniejsze pisma o Matce Bożej"18. W korespondencji z władzami i instytucjami świeckimi Bractwo jako właściciel biblioteki formułowało cel bardziej „narodowo i oświatowo: w kierunku narodowym polskim, biblioteka ma służyć młodym" ${ }^{\prime 1}$. Organizatorzy książnicy deklarowali jej katolicki charakter:

15 Księga pamiątkowa dziesięciolecia Pomorza 1920-1930, Toruń 1930, s. 470; organizacje kulturalno-oświatowe działające na Podgórzu w 1930 r.: Stowarzyszenie Młodzieży Katolickiej, Towarzystwo Gimnastyczne „Sokół”, Towarzystwo Śpiewu „Halka”, Towarzystwo Chóru Kościelnego „Piusa X”, Towarzystwo Opieki nad Ubogimi, Towarzystwo Katolickich Robotników Polskich, Bractwo Kurkowe, Stowarzyszenie Właścicieli Domów, Towarzystwo Inwalidów Wojennych, Podgórski Klub Sportowy, Towarzystwo Hodowców Gołębi Pocztowych „Rozwój”, ale też Ochotnicza Straż Pożarna, Teatr Ludowy, LOPP, Związek Strzelecki, Towarzystwo Powstańców i Wojaków, Zjednoczenie Zawodowe Polskie.

16 Bractwo NMP w Podgórzu i jego owocna działalność, „Słowo Pomorskie” 1930, nr 195 (24 VIII), s. 9; Statut Bractwa Niepokalanie Poczętej Najświętszej Marji Panny Królowej Polski w Podgórzu - koło Torunia, Toruń [1934]; P. Kurlenda, dz. cyt., s. 46; K. Tomkowiak, Biblioteka Bractwa..., s. 425-437.

17 Archiwum Państwowe w Toruniu [dalej cyt. APT], Inspektorat Szkolny w Toruniu [1879] 1920-1939 [dalej cyt. IST], sygn. 131, k. 61; K. Tomkowiak, Biblioteka Bractwa..., s. $425-437$.

18 Statut Bractwa Niepokalanie..., s. 14.

19 Archiwum Państwowe w Bydgoszczy [dalej cyt. APB], Kuratorium Okręgu Szkolnego Pomorskiego w Toruniu [1901] 1920-1939 [dalej cyt. KOSP], sygn. 164, k. 89. 
„miała szerzyć wśród społeczeństwa wiedzę religijną a zwłaszcza o Matce Boskiej oraz wiedzę narodową"20. Zarząd Bractwa podkreślał potrzebę gromadzenia literatury katolicko-narodowej, ale i klasyki, dzieł Mickiewicza, Słowackiego, Sienkiewicza, Kraszewskiego ${ }^{21}$. W kwietniu 1930 r. informowano parafian na Podgórzu o tym, że „w ostatnim czasie Bractwo Niepok. Poczęcia nabyło poważną bibliotekę, przeważnie treści religijnej - aż 500 tomów, z której korzystać mogą wszyscy parafianie"22. Bibliotekę prowadził Leon Szymański w swym mieszkaniu prywatnym (ul. Pułaskiego 50, późniejsza nazwa ulicy Głównej ${ }^{23}$ ). Łożył on też na jej utrzyma$n^{24}{ }^{24}$. Na podstawie wspomnień T. Zakrzewskiego i córki L. Szymańskiego - M. T. Cieślak można ustalić, że biblioteka na początku swego istnienia mieściła się w mieszkaniu państwa Szymańskich, później, aż do końca września 1939 r., była usytuowana w kruchcie podgórskiego kościoła parafialnego ${ }^{25}$. Leon Szymański w okresie międzywojennym pozostał jednocześnie prezesem Bractwa oraz jednym z jego bibliotekarzy ${ }^{26}$. Artykuł 5 Statutu Bractwa podawał, że w skład Zarządu wchodził także bibliotekarz, który na mocy art. 5 p. 8 „prowadził katalogi, wypożyczał książki i odpowiadał za całość biblioteki”27. Na przełomie lat 1934/35 zarejestrowano, jako pełniącego funkcję bibliotekarza, Teofila Kosidowskiego, również urzędnika ${ }^{28}$. Wydział Oświaty Pozaszkolnej notował, że inspektorzy pomagali bibliotekarzom Bractwa i stopniowo ich praca przynosiła efekty. Przykładem tego była ocena zaangażowania L. Szymańskiego jako bibliotekarza. Kuratorium w Sprawozdaniu z działalności biblioteki za rok 1931 zauważyło, że książnica rozwija się i jest utrzymywana przez miejscowego kupca: „człowieka prawego i wielkiego bibliofila, który oddał bibliotece bezpłatnie część własnego mieszkania, daje opał, światło,

20 Tamże, k. 87; tamże, sygn. 166, k. 195.

${ }^{21}$ Tamże, k. 87-88.

${ }^{22}$ Jakie sq organizacje w Podgórzu, „Wiadomości Kościelne Parafii Podgórz” 1930, nr 21 (20 IV), s. 4.

23 J. Domasławski, Za Wisła. Rynek na Podgórzu Anno Domini 1907, „Nowości” 2000, nr 25, s. 21; dzisiejsza ulica Poznańska na początku wieku zwana była Rynkową, a w okresie międzywojennym Główną i Pułaskiego.

${ }^{24}$ APB, KOSP, sygn. 164, k. 50; APT, IST, sygn. 131, k. 11.

25 Rozmowa autorki z T. Zakrzewskim z dnia 23 lutego 2004 r.; rozmowa autorki z córką Leona Szymańskiego M. T. Cieślak z dnia 24 marca 2004 r.

26 T. Zakrzewski, Leon Szymański (1892-1939), [w:] TSB, t. 3, Toruń 2002, s. 230.

27 Statut Bractwa Niepokalanie..., s. 16-17.

${ }^{28}$ APT, IST, sygn. 131, k. 88-89, k. 98-99, k. 110-111; inne dane z roku 1932 notują T. Kosidowskiego jako bibliotekarza, por. APT, ISP, sygn. 313, k. 106-107. 
obsługę"29. Księgozbiór w samym tylko 1930 r. wzrósł z 500 do 1003 woluminów, by w roku 1934 liczyć 1500 tomów ${ }^{30}$. „Bractwo zorganizowało bibliotekę według określonego programu"31, jej zbiory podzielone były na: A. Dział Religijny, B. Dział Naukowy, C. Dział Beletrystyczny. Zapewne w ramach działu religijnego zastosowano również podział na: Mariologię, Żywoty Chrystusa Pana, Żywoty Świętych oraz część ogólnokatolicką. Proboszcz parafii podgórskiej bardzo popierał działalność nowej placówki, czego wyrazem był Komunikat z 2 marca $1930 \mathrm{r}^{32}$ Wysoko oceniając zbiory biblioteki, prasa toruńska charakteryzowała jej wartość: „Staranność w doborze dzieł sprawiła, że w bibliotece znalazły się prace wszystkich niemal wybitniejszych pisarzy katolickich naszych i obcych"33. Szczególną troską objęto zbiory o Matce Bożej: „Z dzieł Marjologicznych, Bractwo posiada paręset tomów tj. wszystko co w dobie obecnej w literaturze polskiej nabyć można"34. Jako bibliotekarz Szymański zajmował się stałym uzupełnianiem zbiorów, na które składały się oprócz literatury religijnej i naukowej również dzieła beletrystyczne. Poza książkami biblioteka gromadziła także czasopisma związane z kultem NMP, w tym pisma w języku francuskim, np. dziennik „La Croix” czy miesięcznik paryski „Federation nationale catholique” ${ }^{35}$. Szczególną troską Szymański otaczał wydawnictwa maryjne, wyrazem jego zainteresowania, ale i znajomości zasobu bibliotecznego był stworzony przez niego Katalog dzieł mariologicznych III. Według Tytułu Książek, obecnie znajdujący się w rodzinnym archiwum jego córki, M. T. Cieślak ${ }^{36}$. Składa się on z czterech kart, które zawierają 91 adresów bibliograficznych w układzie według tytułów, z czego 14 pozycji to druki siedemnastowieczne, 26 to druki osiemna-

29 APB, KOSP, sygn. 164, k. 50.

30 Tamże, k. 89; sygn. 166, k. 195; APT, IST, sygn. 131, k. 12, k. 61, k. 88-89, k. 98-99, k. 110-111; Bractwo NMP w Podgórzu i jego owocna działalność..., s. 9; Biblioteki Oświatowe..., s. 146; Statut Bractwa Niepokalanie..., s. 7; P. Kurlenda, dz. cyt., s. 112; w połowie 1930 r. prasa szacowała zbiory biblioteczne na 750 tomów.

${ }^{31}$ Statut Bractwa Niepokalanie..., s. 7.

32 Komunikat Ks. Prob. Domachowskiego, „Wiadomości Kościelne Parafii Podgórz” 1930, nr 14 (2 III), s. 4; donoszono: „Tutejsze Bractwo Niepokalanego Poczęcia Najśw. Marji Panny posiada bibliotekę złożoną z 500 tomów treści religijno narodowej. Do tejże biblioteki ma każdy parafianin przystęp. Ponieważ w Podgórzu nie ma publicznej biblioteki czytelni proszę o jak najgorliwsze korzystanie z biblioteki, która się znajduje w mieszkaniu Pana Leona Szymańskiego, ul. Pułaskiego 50. Ks. Prob. Domachowski”.

${ }_{33}$ Bractwo NMP w Podgórzu i jego owocna działalność..., s. 9.

${ }^{34}$ Statut Bractwa Niepokalanie..., s. 7.

${ }^{35}$ Bractwo NMP w Podgórzu i jego owocna działalność..., s. 9.

${ }^{36}$ Kopia katalogu w prywatnych zbiorach autorki oraz T. Zakrzewskiego. 
stowieczne, $8 \mathrm{z}$ nich to druki dziewiętnastowieczne, a 42 pozycje to druki nowe z początku dwudziestego wieku; jedna pozycja nie posiada daty wydania. W sumie 40 pozycji to starodruki, a 50 to druki nowe, co daje obraz bardzo wartościowego księgozbioru, jednak nadal trudno stwierdzić, jak cenna była pozostała jego część. Wśród nowych druków znajdują się także pozycje wydane w Toruniu przez księdza Franciszka Nowakowskiego: anonimowo opublikowane przez niego Wspomnienia z pielgrzymki do Lourdes (Toruń 1938) czy Żywy Różaniec w parafii. Praktyczny podręcznik do zakładania i prowadzenia Żywego Różańca (Toruń 1938)³7. Jak wspomina M. T. Cieślak ${ }^{38}$, Szymański przyjaźnił się z księdzem Nowakowskim $^{39}$. Dlatego nie dziwi fakt, że bibliotekarz i prezes Bractwa przekazał część zbiorów z tej biblioteki księdzu Nowakowskiemu. Katalog dzieł mariologicznych z 28 lipca 1938 r. na każdej stronie ma zapis „przyjęte 28/VII 38 Ks. F. Nowakowski" ${ }^{\prime 0}$. Trudno określić, czy był to jednorazowy dar Bractwa dla Instytutu Różańcowego (dalej: IR), czy druki te stanowiły warsztat pracy - działalności wydawniczej IR (toruński Mariański Instytut Różańcowy wydawał i brał w komis wydawnictwa o podobnej tematyce, jaką gromadziła biblioteka, np. ks. F. Nowakowskiego Żywy różaniec dzieci, Toruń $1939^{41}$ ), czy też dar był zaczątkiem biblioteki Instytutu (Nowakowski był już wcześniej organizatorem biblioteki publicznej i czytelni w swej parafii w Troszynie k. Ostrołęki ${ }^{42}$ ).

Wnętrze pomieszczeń biblioteki Bractwa obrazuje zdjęcie zamieszczone w Statucie, na którym uwidoczniono trzy szafy biblioteczne, do po-

37 [reklama]: ! Do polskich - katolickich księgarń! (...) należy zwrócić uwagę na (...) Żywy różaniec - ks. Fr. Nowakowskiego (...) Ku uzdrowieniu Polski - ks. Fr. Nowakowskiego (...) Czytanki Żywego różańca (...) zamawianych wprost u autora Ks. Fr. Nowakowskiego, Instytut Wydawnictw Różańcowych, Karnkowo, p. Lipno Warsz. (...), „Przegląd Księgarski” 1938, nr 15-16 (12 IX), s. 100.

38 Rozmowa autorki z M. T. Cieślak z dnia 24 marca $2004 \mathrm{r}$.

39 Ks. J. Kowalski, Franciszek Nowakowski (1885-1974), autor i redaktor czasopism i książek o tematyce różańcowej, działacz społeczny, [w:] Słownik polskich teologów katolickich 1918-1981, pod red. ks. L. Grzebienia SJ, Warszawa 1983, s. 559-560.

40 Statut Maryjnego Instytutu Różańcowego, Toruń 1939, s. III okładki; Diecezja toruńska. Historia i teraźniejszość, t. 15/16/17, Dekanaty toruńskie - I, II, III, pod. red. S. Kardasza, Toruń 1995, s. 177; J. Związek, Franciszek Nowakowski (1885-1974), [w:] Polski słownik biograficzny, t. 23, s. 279-280; od 1936 r. Instytut przeniósł siedzibę do Torunia, od 30 stycznia 1939 r. działał na mocy nowego Statutu jako Maryjny Instytut Różańcowy.

41 [reklama: Wydawnictwa Mariańskiego Instytutu Różańcowego, Toruń, Rybaki 59], dla szkół (...) Rozsyłamy nowości w komis, „Przegląd Księgarski” 1939, nr 22-23 (15 VIII), s. 290; [reklama: Wydawnictwa Mariańskiego Instytutu Różańcowego, Toruń, Rybaki 59], Antykomunistyczne (...) Rozsyłamy nowości w komis, tamże, s. 300.

42 J. Związek, dz. cyt., s. 279-280. 
łowy przeszklone, dwudrzwiowe, ustawione w ciągu pod ścianą; na górze szaf umieszczono krzyże oraz figurę Matki Bożej, nad szafami na ścianie wisiał krzyż $\dot{ }^{43}$. Biblioteka była otwarta codziennie i miała charakter publiczny, była dostępna dla całej parafii. Nie pobierano kaucji od czytelników, ale wypożyczenia były odpłatne, co regulował odrębny Regulamin. Należność za wypożyczenie jednego tomu wynosiła 10 gr (dla porównania cena np. gazetki parafialnej wynosiła również 10 gr), jednak bezrobotni mogli korzystać z biblioteki bezpłatnie. Dochody z opłat za wypożyczenia wyniosły w 1931 r. 200 zł, co mogło pokryć w jednej czwartej wydatki poniesione na oprawę książek ${ }^{44}$. Natomiast z subwencji od miasta Podgórza biblioteka zakupiła szafy i pokryła pozostałe koszty opra$w^{45}$. Prawie wszystkie tomy zostały oprawione w niebieską okładzinę, grzbiet i narożniki w zupełności w tym kolorze, środki w odcieniu niebieskawym ${ }^{46}$. Maria Teresa Cieślak podarowała autorce egzemplarz czasopisma „Róża Duchowna”, na którym znajduje się pieczęć z imieniem, nazwiskiem i adresem Szymańskiego oraz resztki nalepki, białej z otoczką z niebieskiej lamówki, być może z resztką numeru (na ocalałym fragmencie widnieje cyfra 7). Nie można wykluczyć, że w ten właśnie sposób sygnowano czasopisma.

„Wiadomości Kościelne Parafii Podgórz” (dalej: WKPP), propagując hasło „jaka wiara, takie też obyczaje” ${ }^{47}$, gorąco polecały w tekście Czytajcie dobre książki! druki z tejże biblioteki ${ }^{48}$. Artykuł bardzo wyraźnie podkreślał zasługi Bractwa dla „sprawy katolickiej”, uwypuklając założenie „tak obszernej biblioteki o treści religijno-moralnej". Książnicą zainteresowało się również z dużą życzliwością Ministerstwo Wyznań Religijnych i Oświecenia Publicznego (dalej: MWRiOP), otrzymywano dary od Kuratorium Okręgu Szkolnego Pomorskiego, Wydziału Powiatowego, od Księgarni

43 „Słowo Pomorskie” 1930, nr 195 (24 VIII); Statut Bractwa Niepokalanie..., s. 8.

${ }^{44}$ APB, KOSP, sygn. 164, k. 89; APT, IST, sygn. 131, k. 11, k. 61, k. 88-89; sygn. 313, k. 106-107.

${ }^{45}$ APB, KOSP, sygn. 164, k. 68-69.

${ }^{46}$ Rozmowa autorki z M. T. Cieślak z dnia 24 marca 2004 r.

47 Strzeżcie się złych książek!, „Wiadomości Kościelne Parafii Podgórz” 1930, nr 24 (11 V), s. 4.

${ }^{48}$ Czytajcie dobre książkil, „Wiadomości Kościelne Parafii Podgórz” 1930, nr 24 (11 V), s. 4; donoszono: „Mamy w Podgórzu taką bibliotekę, do której wszyscy parafianie mają przystęp. Biblioteka ta jest własnością Bractwa Niepokalanego Poczęcia Najśw. Marji Panny i znajduje się w mieszkaniu p. bibliotekarza Leona Szymańskiego na ul. Pułaskiego. Korzystajcie, kochani parafianie, jak najgorliwiej z tejże placówki i czytajcie książki katolickie!". 
św. Wojciecha w Poznaniu, oo. jezuitów w Krakowie, także prasa toruńska apelowała do społeczeństwa o ofiarność ${ }^{49}$. Maria Teresa Cieślak szacuje, że ocalały po wojnie księgozbiór biblioteki Bractwa, który przechowywał najstarszy syn Szymańskiego, mógł liczyć około 300 woluminów ${ }^{50}$.

Tuż po założeniu biblioteki Bractwa, w kwietniu 1930 r., WKPP podały dane statystyczne o organizacjach podgórskich. Odnotowano wówczas, że Bractwo Niepokalanego Poczęcia Najśw. Marji Panny liczyło 60 członków ${ }^{51}$. Liczebność zrzeszenia w 1934 r. zwiększyła się do 140 osób ${ }^{52}$. W parafii podgórskiej wydawano „Wiadomości Kościelne Parafii Podgórz”, których redaktorem był ksiądz Józef Domachowski ${ }^{53}$. W parafii działał też Komitet Propagandy Katolickiej, który zajmował się promocją poza biblioteką druków o treści katolickiej i narodowej ${ }^{54}$. Książki zalecane przez „władzę duchową” można było nabyć, jak podawały „Wiadomości”, w księgarni Kruszyńskiego na Podgórzu już za 80 gr (1930 r.), podczas gdy cena tejże gazetki parafialnej wynosiła 10 groszy ${ }^{55}$. We wspomnianej księgarni często odbywały się zebrania Bractwa. „Wiadomości” ostrzegały przed lekturą niezaaprobowaną przez Kościół, np. w artykule Strzeżcie się złych książek! potępiano wydawnictwa, które „szerzą fałsz i truciznę moralną”, dostrzegając w słowie drukowanym przydatny środek oświatowy ${ }^{56}$. Na łamach „Wiadomości” gorąco polecano, w tekście Czytajcie dobre książki!, pozycje z biblioteki Bractwa: „Mamy w Podgórzu taką bibliotekę, do której wszyscy parafianie mają przystęp. Biblioteka ta jest własnością Bractwa Niepokalanego Poczęcia Najśw. Marji Panny i znajduje się w mieszkaniu

${ }^{49}$ Bractwo NMP w Podgórzu i jego owocna działalność..., s. 9.

${ }^{50}$ Rozmowa autorki z M. T. Cieślak z dnia 9 lutego 2005 r.; najstarszy syn Leona Szymańskiego, ksiądz kanonik Henryk Szymański (ur. 1924 r.), mieszkał w Gnieźnie, zmarł w 2004 r., księgozbiór, którym dysponował, pozostaje w Gnieźnie. Nieliczne pozycje z tejże biblioteki - nie mniej niż 6 książek - u siostry M. T. Cieślak.

51 Jakie sq organizacje w Podgórzu..., s. 4.

52 Statut Bractwa Niepokalanie..., s. 11.

53 T. Zakrzewski, Ks. Józef Domachowski (1876-1940), proboszcz parafii św. Piotra i Pawła na toruńskim Podgórzu, „Nowości” 1996, nr 260, s. 10.

${ }^{54}$ P. Kurlenda, dz. cyt., s. 112-113.

55 „Wiadomości Kościelne Parafii Podgórz” 1930, nr 9 (26 I), s. 4.

56 Strzeżcie się złych książek!..., s. 4; w tekście podano przykład sprzedawanych „piśmideł”, w których znalazły się „podłe napaści na Kościół i wiarę katolicką”, potępiano m.in. „kupno sprzedawanej w Polsce biblii protestanckiej oraz broszur i ulotek sekt”. Inne ostrzeżenia i zakazy w parafialnej prasie podgórskiej zob.: „Wiadomości Kościelne Parafii Podgórz": Bezbożnicy przy pracy w parafii podgórskiej, 1931, nr 9 (25 I), s. 4; Adwentyści, 1931, nr 11 (8 II), s. 4; Ostrzeżenie, 1931, nr 47 (18 X), s. 4; Dzielny prezes Akcji Katolickiej, 1933, nr 38 (13 VIII), s. 4. 
p. bibliotekarza Leona Szymańskiego na ul. Pułaskiego. Korzystajcie, kochani parafianie, jak najgorliwiej z tejże placówki i czytajcie książki katolickie!" ${ }^{57}$. Redakcja gazety parafialnej zachęcała również Bractwo do innej, ciekawej formy upowszechniania czytelnictwa - do ustawiania w kościołach tzw. półek z książkami o treści religijnej. W taki sposób można było wybrać i nabyć książkę, gdyż każda była opatrzona ceną; kwotę wrzucało się do skarbonki, przymocowanej do półki ${ }^{58}$.

\section{Biblioteka parafii św. św. Piotra i Pawła}

W okresie dwudziestolecia międzywojennego przyjęło się traktować biblioteki parafialne jako placówki prowadzące formę pracy oświatowej, wydawano nawet poradniki biblioteczne ${ }^{59}$. Podobnie jak w innych ośrodkach, także w parafii św. św. Piotra i Pawła funkcjonowała książnica. W parafii Podgórz biblioteka i czytelnia powstały z inicjatywy ks. Domachowskiego - dzięki jego staraniom powiększały się zbiory książek i prasy. Dostęp do czasopism zapewniała również prenumerata. Piotr Kurlenda wymienia 26 tytułów prenumerowanych w podgórskiej parafii. Czasopisma abonowały zarówno osoby prywatne, organizacje kościelne, jak i sama parafia. W parafii Podgórz w 1930 r. prenumeratą objęto w sumie 1440 egzemplarzy czasopism ${ }^{60}$. Zbiory tej książnicy parafial-

${ }^{57}$ Czytajcie dobre książki!..., s. 4.

${ }^{58}$ Tamże; ten typ kolportażu miał nawiązywać do angielskiego zwyczaju z 1884 r., kiedy to ówczesny kardynał angielski Vaughan założył stowarzyszenie Katolickie Towarzystwo Prawdy oraz wprowadził umieszczanie półek z książkami o treści religijnej. Redakcja zapewniała, że ten typ kolportażu był zastosowany w archidiecezji wileńskiej, i oceniła pozytywnie jego skuteczność.

59 L. Grzebień, Biblioteki kościelne, [w:] Encyklopedia katolicka [dalej cyt. EK], t. II, Lublin 1995, s. 505-510; M. Kunowska-Porębna, Czytelnictwo religijne, [w:] EK, t. III, Lublin 1995, s. 954-959; biblioteki kościelne (katolickie) oraz organizacje religijne w Toruniu i Podgórzu rozwijały się w okresie międzywojnia dynamicznie. Początków tego zjawiska należy szukać od połowy XIX w., kiedy to rozwinął się ruch mający na celu upowszechnianie dobrej książki i prasy, zaowocowało to tworzeniem się bibliotekarstwa parafialnego (np. w Austrii działał Pius-Verei, a w Niemczech stowarzyszenie Borromäus-Verein), w Polsce na początku XX w. istniały już projekty bibliotek parafialnych, a w diecezji chełmińskiej założono lokalne „czytelnie okrężne”.

${ }^{60}$ P. Kurlenda, dz. cyt., s. 113 n.; w latach 1930-1933 podgórska parafia prenumerowała czasopisma: „Chorągiew Maryi”, „Doniesienia Archidiecezjalnego Instytutu Akcji Katolickiej”, „Dzwonek III Zakonu”, „Głos Katolicki”, „Hufiec”, „Kierownik Młodzieży”, „Królowa Apostołów”, „Mały Misjonarz”, „Młoda Polka”, „Młodzież Misyjna”, „Nasz Misjonarz”, „Orędownik Krucjaty Eucharystycznej”, „Posłaniec Serca Jezusowego”, „Przewodnik Kato- 
nej liczyły nie mniej niż 1500 tomów, gdyż tyle udało się uratować przed okupantem organiście Marcinkowskiemu i Feliksowi Tomaszewskiemu. W oparciu o ten zasób 3 maja 1945 r. biblioteka podgórskiej parafii została otwarta ponownie ${ }^{61}$.

\section{Biblioteki katolickich stowarzyszeń młodzieżowych}

B iblioteki i czytelnie wyposażone w niewielkie księgozbiory powstaB wały zwykle przy bractwach i stowarzyszeniach religijnych; zdecydowanie najczęściej na tworzenie księgozbiorów decydowały się sodalicje mariańskie i katolickie stowarzyszenia młodzieżowe. Podobnie sytuacja kształtowała się na Podgórzu, gdzie obie młodzieżowe organizacje religijne posiadały swoje księgozbiory. Bibliotekę parafialną zorganizowało Stowarzyszenie Młodzieży Polskiej Męskiej - Podgórz ${ }^{62}$. Jej zbiorami opiekowali się kolejno: Konrad Nawra (1923 r.), Stanisław Zuchowski (1924 r.), Feliks Kempa (1926 r.), Aleksander Lewandowski (1928 r.), Franciszek Muszytowski oraz jego zastępca Jan Grabowski (1930 r.) ${ }^{63}$, Jan Krajewski (1931 r.). Księgozbiór liczył 261 pozycji w 1920 r., 272 w 1925, 273 tytuły w latach 1926-1928, 263 w 1930 i 283 pozycje w 1931 r. Prowadzono również działalność upowszechnieniową; do tych poczynań można zaliczyć zorganizowanie przez Katolickie Stowarzyszenie Młodzieży Męskiej wystawy książek katolickich, obrazów i prac ręcznych na Podgórzu w dniach 9-11 czerwca 1935 r. Jej uroczystego otwarcia dokonano w pierwszy dzień Zielonych Świątek bezpośrednio po sumie. Ekspozycję można było zwiedzać po nabożeństwach, wstęp nie wymagał opłat. Wystawa była przejawem działań, jakie propagowała Akcja Katolicka: „Akcja Katolicka to katolik aktywny, Świętość i Twórczość” ${ }^{64}$. Swą bibliotekę parafialną założyło także Stowarzyszenie Młodzieży Polskiej Żeń-

licki”, „Przewodnik Miłosierdzia”, „Przewodnik Społeczny”, ,Przyjaciel Młodzieży”, „,Robotnik”, , ,Rocznik PDRW”, „Rocznik św. Dziecięctwa”, „Rodzina Chrześcijańska”, „Ruch Katolicki”, „,Rycerz Niepokalanej”, „Sprawie Służy”, „Wiara i Życie”.

61 Uroczystość poświęcenia i otwarcia biblioteki parafialnej św. Piotra i Pawła na Podgórzu, „Nowy Dzień Robotnika” 1945, nr 36 (8 V), s. 4; W. Ciszewska, Książka w Toruniu w latach 1945-1950. Ruch wydawniczo-księgarski, Toruń 2005, s. 33.

62 P. Kurlenda, dz. cyt., s. 110-112.

${ }^{63}$ Sprawozdanie z działalności Stowarzyszenia Młodzieży Polskiej w Podgórzu w r[oku]1929, „Wiadomości Kościelne Parafii Podgórz” 1930, nr 13-14 (23 II-2 III), s. 4.

64 „Wiadomości Kościelne Parafii Podgórz” 1935, nr 28 (9 VI), s. 4. 
skiej - Podgórz ${ }^{65}$. Spis bibliotek oświatowych odnotował ją w klasztorze, określając jej lokal jako mieszczący się „przy kościele”, podawał również 1919 r. jako datę jej założenia. Pieczę nad biblioteką powierzono w latach 1936-1938 Rozalii Warmiewskiej i Agnieszce Woźnej (jako jej zastępczyni), a w 1938 r. A. Madtalównie i C. Muszytowskiej (jako jej zastępczyni). Książnica była dostępna dla członków nieodpłatnie, była otwarta raz w tygodniu przez jedną godzinę, gromadziła zbiory w języku polskim. W 1929 r. posiadała 79 woluminów ${ }^{66}$.

Z podgórską parafią mocno związana była działalność chórów kościelnych, które również dysponowały swymi księgozbiorami. Męski Chór Kościelny im. Piusa X w Podgórzu powstał przed 30 stycznia $1930 \mathrm{r}$. Pierwszym jego prezesem był mistrz fryzjerski Ludwik Wierzchowski, a patronem ksiądz proboszcz ${ }^{67}$. Kolejnym prezesem został ks. wikary Walerian Panek, w 1930 r. chór liczył 50 członków ${ }^{68}$. Próby odbywały się w mieszkaniu W.[iktora] Skrzypnika, którego lokal określano później mianem „Domu Polskiego”. Zarząd wybrany na rok 1930 powierzył opiekę nad biblioteką Męskiego Chóru Kościelnego im. Piusa X w Podgórzu Feliksowi Kempie. W następnej kadencji, za prezesury ks. wikarego Edmunda Schreibera, bibliotekarzem mianowano Jana Karnowskiego juniora. W takim kształcie organizacyjnym chór działał do grudnia $1933 \mathrm{r}$., można przypuszczać, że jego biblioteka również. Ksiądz proboszcz Domachowski w grudniu 1937 r. ponownie zainicjował powstanie „nowego” Męskiego Chóru Kościelnego, również pod patronatem Piusa X. Jego prezesem został ks. wikariusz Bernard Sadecki. W tym samym czasie przejęto także książnice; był to zapewne księgozbiór poprzedniej biblioteki męskiego chóru, jej bibliotekarzem został Bernard Kowalkowski ${ }^{69}$.

Wśród organizacji działających na Podgórzu najwcześniej bibliotekę posiadało istniejące na terenie parafii Katolickie Towarzystwo Robotników Polskich (dalej: KTRP). Powstało ono na Podgórzu 29 marca 1908 r. i wchodziło w skład Związku Katolickich Towarzystw Robotników Pol-

${ }^{6}$ P. Kurlenda, dz. cyt., s. 112.

${ }^{66}$ Biblioteki Oświatowe..., s. 146. Biblioteka Stowarzyszenia Młodych Polek była notowana pod numerem 561.

67 P. Kurlenda, dz. cyt., s. 64; T. Zakrzewski, Dzieje chórów..., s. 127; kolejno prezesami Chóru Kościelnego im. Piusa X w Podgórzu byli w 1929 r. Ludwik Wierzchowski, w 1933 r. Michał Zdunek, w 1934 r. Szymon Lemański.

${ }^{68}$ Jakie sq organizacje w Podgórzu..., s. 4.

${ }^{69}$ Męski Chór kościelny im. Piusa X w Podgórzu, „Wiadomości Kościelne Parafii Podgórz" 1930, nr 12 (16 II), s. 4; T. Zakrzewski, Dzieje chórów..., s. 127, 130, 135. 
skich (dalej: ZKTRP) w archidiecezji gnieźnieńskiej i poznańskiej ${ }^{70}$. Inicjatorem i patronem tego związku był ks. proboszcz Domachowski ${ }^{71}$, który już 8 kwietnia 1908 r. o planach założenia biblioteki dla robotników pisał do Sekretarza Generalnego ZKTRP w Poznaniu ks. Stanisława Adamskiego ${ }^{72}$. Członkowie KTRP, w dużej części robotnicy sezonowi i często kolejarze $^{73}$, zajmowali się organizowaniem różnych imprez, np. 2 lipca 1933 r. uroczyście obchodzono Dzień Robotnika Katolickiego. Towarzystwo organizowało również odczyty o tematyce religijnej oraz propagowało „odpowiednią" literaturę ${ }^{74}$. W siedzibie KTRP, w lokalu Skrzypnika i Kruszyńskiego („Hotel-Central”), funkcjonowała również biblioteka, której zasoby sukcesywnie rosły. Zapoczątkowały ją zakupy pojedynczych książek, które ułatwiły członkom Towarzystwa kontakt ze słowem drukowanym. W pierwszych Sprawozdaniach nie odnotowano statystyki wypożyczeń, ale od momentu powstania biblioteki istniało stanowisko bibliotekarza, pierwszym był Kazimierz Czerniewski (1908 r.) ${ }^{75}$. Kolejno po nim piastowali tę funkcję: Franciszek Szafrański i jego zastępca Szczepan Gołota (1909 r.) ${ }^{76}$, który samodzielnie odpowiadał za bibliotekę już w 1910 r. $^{77}$ Właśnie tę datę podawało Towarzystwo jako początek działalności swej biblioteki. Podgórskie KTRP było właścicielem księgozbioru, ale sama książnica mieściła się w 1929 r. w lokalu przy ulicy Pułaskiego 10 w parafii. Dostępna tylko dla członków, była otwarta jeden raz w tygodniu przez dwie godziny. Na jej zbiory składało się 136 woluminów. W okresie od 1 stycznia do 31 grudnia 1929 r. odnotowała 65 czytelników i 107 wypożyczeń, a na jej utrzymanie przeznaczono $63 \mathrm{zt}^{78}$. W 1932 r. posiadała księgozbiór niebeletrystyczny obejmujący 57 pozycji, tyleż odnotowano wówczas wypożyczeń, zarejestrowano 15 czytelników (samych mężczyzn). Biblioteka miała charakter stały, była bezpłat-

\footnotetext{
${ }^{70}$ APT, Akta miasta Podgórza [dalej cyt. AmP], sygn. 2248; 25-lecie Katol.[ickiego] Towarzystwa Robotników Polskich, „Wiadomości Kościelne Parafii Podgórz” 1933, nr 32 (2 VIII), s. 4.

71 APT, AmP, sygn. 2248, k. 420; „Słowo Pomorskie” 1932, nr 165 (21 VII), s. 5.

72 APT, AmP, sygn. 2248, k. 447, 450.

73 Tamże, Spis członków KTRP w Podgórzu z 1 II 1933.

${ }^{74}$ Jakie sq organizacje..., s. 4; Statystyka parafialna w Podgórzu..., s. 4.

75 APT, AmP, sygn. 2248, k. 420.

76 Tamże, k. 403.

77 Tamże, sygn. 2248, k. 397.

${ }^{78}$ Biblioteki Oświatowe..., s. 146; biblioteka Towarzystwa Katolickich Robotników w spisie była umieszczona pod numerem 560 .
} 
na ${ }^{79}$; w latach $1933 / 34$ wykazywała nadal 57 pozycji i 15 czytelników ${ }^{80}$. Informacje z kolejnych lat powtarzają się, trudno zatem ocenić je jako wiarygodne. Natomiast nie wzbudzają podejrzeń dane dotyczące obsady bibliotekarzy, chociaż biorąc pod uwagę ich częstą rotację, można założyć, że nie były to osoby z fachowym bibliotekarskim przygotowaniem. Jako bibliotekarzy Sprawozdania z okresu międzywojennego wymieniają: Władysława Jankowskiego, Jana Sobczaka, Józefa Nowaka, Władysława Graczyka, Tomasza Niedźwieckiego, Piotra Aleksandera, Józefa Banasiaka i jego zastępcę Franciszka Cylka ${ }^{81}$. Ostatnim bibliotekarzem, wybranym w styczniu 1939 r., został Jan Witt, a jego zastępcą Leon Barczak $^{82}$.

\section{Inne biblioteki Podgórza}

O pozostałych księgozbiorach dostępnych w różnym stopniu dla społeczności podgórskiej nie zachowało się wiele informacji. Niewielką biblioteką dysponował Związek Strzelecki Okręgu VIII. Powiat Toruń. Oddział Podgórz. Starania o utworzenie książnicy rozpoczęto od pozyskania 60 książek, biblioteka miała charakter ruchomy, była dostępna tylko dla członków Związku Strzeleckiego. W księgozbiorze znalazły się 64 woluminy, w tym 54 pozycje z beletrystyki i 10 pozycji naukowych; w bibliotece zarejestrowano 27 czytelników, w tym 17 mężczyzn i 10 kobiet. Placówkę zlokalizowano w świetlicy Związku w hali balonowej, bibliotekarką została Wanda Czermerowska, która pobierała należność w wysokości 25 gr od członków; zwolnione z opłat były m.in. osoby bezrobotne. Biblioteka działała od 7 listopada $1931 \mathrm{r}^{83}$

Dzięki powstaniu Centrali Powiatowych Bibliotek Ruchomych (dalej: CPBR) powiatu toruńskiego w grudniu 1934 r. miasto Podgórz otrzymało 100 książek na zapoczątkowanie biblioteki stałej oraz perspektywę pozyskania kolejnych pozycji z MWRiOP ${ }^{84}$. Na Podgórzu w 1935 r. odnotowano też bibliotekę ruchomą. Określona została jako „stara”, co oznacza,

79 APT, IST, sygn. 313, k. 108-109.

80 Tamże, sygn. 131, k. 98-99.

${ }^{81}$ APT, AmP, sygn. 2248.

82 Tamże, k. 7.

${ }^{83}$ APT, IST, sygn. 131, k. 65.

${ }^{84}$ APB, KOSP, sygn. 3574: Biblioteki na terenie miasta i powiatu toruńskiego 1929-1935 . 
że powstała przed oddaniem do użytku przez CPBR powiatu toruńskiego 50 nowych kompletów bibliotek ruchomych i znajdowała się wśród 36 „starych" kompletów bibliotek ruchomych ${ }^{85}$. Być może wyjaśnienia dostarczy Wykaz bibliotek publicznych w powiecie toruńskim [1932-1935], który pod numerem 15 wykazywał książnice samorządowe Podgórza i określał ich zasób na 400 tomów. Z wyjaśnień wynikało również, że nie chodziło wówczas o biblioteki ruchome Towarzystwa Czytelni Ludowych (dalej: TCL), których w powiecie toruńskim w ogóle nie było. Działalność bibliotek samorządowych powiatu toruńskiego oceniano wówczas pozytywnie ${ }^{86}$.

W latach 30. działały na Podgórzu, podobnie jak na Rudaku i Stawkach, punkty biblioteczne. Na ich zasób składały się gotowe komplety, na Podgórzu toruński Inspektorat Szkolny. Oddział Oświaty Pozaszkolnej (dalej: IST OOP) odnotował bowiem tego typu rozpowszechnianie literatury. Wypożyczano pozycje na czas określony. Zarejestrowano, że w podgórskim punkcie w komplecie znalazło się: 49 pozycji beletrystycznych, 9 naukowych, 58 o tematyce religijnej. Wypożyczono 140 prac naukowych, 20 z beletrystyki i 160 o tematyce religijnej. Wśród 55 czytelników znalazły się 32 kobiety i 23 mężczyzn ${ }^{87}$.

W latach sprawozdawczych 1932/1934 IST OOP odnotował działalność na Podgórzu biblioteki Wydziału Powiatowego. Jej zbiory liczyły 76 książek, w tym 66 z beletrystyki i 10 naukowych. Dokonano 815 wypożyczeń, w tym 819 pozycji z beletrystyki i 5 dzieł naukowych. Zarejestrowano wówczas 54 czytelników, w tym 30 mężczyzn i 24 kobiety, funkcję bibliotekarki pełniła Aniela Stefurakówna. Biblioteka miała charakter ruchomy, a wypożyczenia odbywały się bezpłatnie. W kolejnym roku na 58 pozycji rejestrowano 49 beletrystycznych i 9 naukowych, wypożyczono 160 książek, w tym 140 beletrystycznych i 20 naukowych, a wśród 55 zarejestrowanych czytelników było 23 mężczyzn i 23 kobiety, bibliotekarką była Zofia Gajewska ${ }^{88}$.

${ }^{85}$ Broń i amunicja na froncie oświaty. Scalenie ducha państwowo-narodowego przez Biblioteki Ruchome, „Dzień Pomorski” 1935, nr 24 (28 I), s. 6; APB, KOSP, sygn. 3574.

${ }^{86}$ APT, IST, sygn. 131: Biblioteki na terenie obwodu szkolnego toruńskiego 1932-1935, k. 2: Wykaz bibliotek publicznych w powiecie toruńskim [1932-1935], nr 15 biblioteki samorządowe.

87 Tamże, k. 19.

${ }_{88}$ Tamże, sygn. 131, k. 87, 88-89. Zacytowane dane liczbowe nie stanowią podanej sumy. Jest to wynikiem prawdopodobnie błędnych informacji w sprawozdaniach. 
Trudno dokładnie określić, od kiedy działała na Podgórzu biblioteka Towarzystwa Czytelni Ludowych ${ }^{89}$, gdyż już w Sprawozdaniu Katolickiego Towarzystwa Robotników Polskich za rok 1911 bibliotekarz Szczepan Gołota stwierdził: „Wobec istniejącej tutaj Czytelni Ludowej nie warto osobnej biblioteki zakładać. Najchętniej czytają książki treści religijnej" ${ }^{90}$. W okresie dwudziestolecia międzywojennego na Podgórzu działała biblioteka TCL jako filia koła toruńskiego. W Sprawozdaniu toruńskiego koła TCL z roku 1937, które przedłożono 30 kwietnia 1938 r., prezes Zygmunt Mocarski, ówczesny dyrektor Książnicy Miejskiej, podkreślił, że „największy przyrost notuje filia biblioteczna im M. Drzymały na Podgórzu" ${ }^{11}$. Można także przypuszczać, że w szkołach podgórskich istniały dostępne dla nauczycieli i uczniów księgozbiory. Do Kuratorium Oświaty Okręgu Szkolnego Pomorskiego wpłynęło Sprawozdanie kierownika szkoły (bibliotekarza) ze stanu biblioteki dla młodzieży szkolnej rok szkolny 1924/1925 z dn. 15 XI 1925. Dotyczyło ono m.in. biblioteki publicznej szkoły powszechnej siedmioklasowej z polskim językiem nauczania. Wynika z niego, że 526 uczniów miało do dyspozycji w bibliotece szkolnej 378 książek w języku polskim, co dawało przyrost zbiorów w stosunku do poprzedniego roku sprawozdawczego o 131 tytułów. Zarejestrowano 395 czytelników, a jako bibliotekarkę podawano J. Peszkowską ${ }^{92}$. Inne Sprawozdanie, za rok szkolny 1927/28, wykazuje wzrastającą liczbę dzieł z 398 (stan na 30 czerwca 1927 r.) do 609 (stan na 31 lipca 1928 r.), w tomach: z 448 na 681 woluminów. Wszystkie pozycje były w języku polskim. 1 grudnia 1927 r. na liczbę 554 uczniów (276 chłopców, 278 dziewcząt) wypożyczających było 326 osób, w tym 141 chłopców i 185 dziewcząt. W sumie w ciągu roku sprawozdawczego wypożyczono 681 tomów. Abonowano czasopisma „Płomyk” i „Płomyczek” ${ }^{\text {. }}$.

Nie można stwierdzić, czy w okresie dwudziestolecia działała biblioteka w innej podgórskiej placówce edukacyjnej - w Szkole Dokształcającej Zawodowej (Fortbildungsschule zu Podgórz). Szkoła ta funkcjonowała na Podgórzu, podobnie jak inne tego typu placówki w miastach pruskich. Jej zachowany inwentarz (Inventarien-Verzeichnis der Fortbildungsschu-

\footnotetext{
${ }^{89}$ Podgórskiej filii TCL nie wymienia E. Sławińska, Kulturotwórcza rola Towarzystwa Czytelni Ludowych na Pomorzu Gdańskim (1880-1939), Bydgoszcz 1989.

90 APT, AmP, sygn. 2248, k. 393.

91 „Słowo Pomorskie” 1938, nr 75 (1 IV), s. 10; 1939, nr 81 (7 IV), s. 7.

${ }_{92}$ APB, KOSP, sygn. 3566a, sprawozdanie publicznej szkoły powszechnej 7-klasowej w Podgórzu z j. polskim nauczania - r. szk. 1924/1925.

${ }_{93}$ Tamże, sygn. 3567a, k. 51.
} 
le zu Podgórz (Westpr.)) z 1920 r. wykazywał niewielkie księgozbiory: bibliotekę nauczycielską (Lehrerbücherei) oraz bibliotekę uczniowską (Schülerbücherei). Jednak dokumentacja szkoły z okresu międzywojennego nie podaje żadnych informacji o działalności biblioteki ${ }^{94}$.

\section{Podsumowanie}

$\mathrm{N}_{\mathrm{s}}^{\mathrm{a}}$ a podstawie zachowanych źródeł można ocenić potencjał środowiska czytelniczego na Podgórzu w latach 1920-1939 jako zaskakująco dobry. Chociaż miejscowość ta nie doczekała się samodzielnej, odrębnej biblioteki o charakterze publicznym, biblioteki, która byłaby finansowana przez samorząd lokalny, to istniejące księgozbiory, szczególnie książnica Bractwa Niepokalanie Poczętej Najśw. Marji Panny Królowej Polski czy biblioteka parafialna, mogły imponować zasobnością zbioru jak i charakterem swej działalności. Bibliotekę Bractwa słusznie WKPP nazywają „poważną” i podkreślają jej użyteczność dla wspólnoty parafialnej. Nie sposób przecenić jej oddziaływania na całą społeczność podgórską, gdyż biblioteka Bractwa na Podgórzu w środowisku tym pełniła rolę książnicy publicznej. Inne liczne organizacje podgórskie posiadały niewielkie księgozbiory. Ta prestiżowa i honorowa funkcja wynikała zapewne z roli, jaką samo Bractwo odgrywało w życiu społecznym i kulturalnym Podgórza, oraz z faktu, że w jego szeregach znaleźli się tak zacni członkowie, jak kupiec L. Szymański - jej założyciel i „sponsor” czy M. Noga - szanowany rzemieślnik i honorowy obywatel Podgórza. Wśród zasłużonych dla rozwoju czytelnictwa na Podgórzu nie można pominąć innej osoby, księdza proboszcza J. Domachowskiego, który troszczył się o zasoby podgórskich bibliotek i o dostęp najbiedniejszych mieszkańców miasta do słowa drukowanego. Ważną rolę odgrywały też niewielkie biblioteczki, które służyły zamkniętemu gronu członków organizacji kościelnych, kulturalno-oświatowych czy szkolnych. Z pewnością zalecenia co do doboru prasy i książki, ostrzeżenia w czasopismach parafialnych nie były przejawem tolerancji, ale analiza poczynań innych organizacji katolickich $w$ tej materii wykazuje, że niczym nie różniły się od podgórskich „zaleceń” i „ostrze-

${ }^{94}$ APT, AmP, sygn. 1706; sygn. 1719: Akta dotyczqce szkoły dokształcającej na Podgórzu 1920-1937, Inventarien-Verzeichnis der Fortbildungsschule zu Podgórz (Westpr.) 1920; sygn. 1720: Szkoła Dokształcająca [Zawodowa] 1922-1931, Szkoła Dokształcajaca [Zawodowa] 1931-1934. 
żeń"95. Należy zauważyć, iż prezentowany stan badań nad bibliotekami podgórskimi w okresie międzywojennym może ulec zmianie. Część zbiorów nadal znajduje się w rękach prywatnych, jak wzmiankowany Katalog dzieł mariologicznych. Informacje o działalności tych bibliotek mogą być zawarte również w drukach ulotnych, nie w pełni zachowanych. Można założyć, że istniejące wówczas różnorodne organizacje kulturalno-oświatowe na Podgórzu mogły posiadać choćby małe księgozbiory. Monografia Podgórza, wnikliwie dokumentująca jego dzieje w okresie międzywojennym, zapewne uzupełni informacje o środowisku czytelniczym i bibliotekach tego okresu.

\section{Libraries in Podgórz near Toruń in years 1920-1939 Abstract}

This article is the first attempt to characterize Podgórz's library offer in years 1920-1939. The turning points is on the one hand the return of Pomerania, including Podgórz, to Poland following years of annexation, and on the other hand the outbreak of World War II in 1939, which completely damaged most of the library's collection. Podgórz was a town situated on the border between the Pomerania (Pomorskie) and Poznań region, on the left bank of the Vistula river. The final union of the towns (Torun and Podgórz) took place on the 1 April 1938. The purpose of the article is to note down all libraries existing then in Podgórz. First was described the biggest library collections in Podgórz: Lending Library of Sodality St. Mary's Queen Crown's of Poland (Biblioteka Bractwa Niepokalanie Poczętej NMP Królowej Korony Polskiej). Next was analysed libraries religious organizations as well as societies and associations libraries. Podgórz's libraries offer in years 1920-1939 seems very interesting. Decidedly the biggest number of libraries existed within the framework of different societies and organizations, thanks to them that the professional literature was readily accessible for different professional groups dwelling in Podgórz.

${ }^{95}$ Jak potężną prasę posiadają bezbożnicy, „Wiadomości Kościelne Parafii Podgórz” 1932, nr 24 (8 V), s. 4; Musimy zwalczyć to szkodliwe pismo [Tajny Detektyw], „Wiadomości Kościelne Parafii Podgórz” 1932, nr 37 (7 VIII), s. 4; Czy posiadamy powieść katolickq?, „Wiadomości Kościelne Parafii Podgórz” 1933, nr 37 (6 VIII), s. 4. 